\title{
触 New Disease Reports \\ Crepe jasmine rust caused by Uredo manilensis newly reported in Cuba
}

\author{
E. Martínez-de la Parte ${ }^{1 *}$, T. Cantillo-Pérez $^{1}$, D. García ${ }^{1}$ and D. Guerrero-Barriel ${ }^{2}$ \\ ${ }^{1}$ Central Plant Quarantine Laboratory, Ministry of Agriculture of Cuba, Ayuntamiento \#231 entre San Pedro y Lombillo, \\ Plaza de la Revolución, Havana, 10400, Cuba; ${ }^{2}$ Santiago de Cuba Provincial Plant Protection Laboratory, Ministry of \\ Agriculture of Cuba
}

*E-mail: micologia@sanidadvegetal.cu

Received: 12 Mar 2011. Published: 29 Jun 2011. Keywords: Tabernaemontana divaricata, Puccinia engleriana, Puccinia morobensis.

Crepe jasmine, Tabernaemontana divaricata (Apocynaceae), is a popular flowering shrub in Cuba. Native of Southeast Asia, it is one of approximately 100 ornamental species in the genus. In March 2010, a rust was observed on leaves of plants in a garden in Santiago de Cuba city and on landscape plants in several municipalities of Havana city. Leaf lesions began as chlorotic flecks that expanded into necrotic spots with orange-to-reddish brown, subepidermal uredinia; brown telia developed on the abaxial side of leaves (Fig. 1). Urediniospores were one-celled, initially hyaline, minutely echinulate and spherical, turning dark orange, and measuring (23) 26-30 (32) x (20) 24-26 (28) $\mu \mathrm{m}$ (Fig. 2). Teliospores were (28) 32-36 (42) x (20) 22-26 (28) $\mu \mathrm{m}$, two-celled, ellipsoidal to ovoid, echinulate, constricted at the septum, reddish brown, and had 0.8 $\mu \mathrm{m}$ thick spore walls (Fig. 3); pedicels were persistent and hyaline. Attributes for urediniospores were consistent with those from the original description of Uredo manilensis on T. coronariae in Manila, Philippines (Sydow \& Sydow, 1910). However, there were no reports of a telial stage for this rust. Attributes for urediniospores were consistent with those described from T. divaricata in Florida, USA (Perez et al., 2008), which contained teliospores that matched in form and colour with those found in Cuba. However, Cuban specimens had teliospores somewhat larger than Florida specimens ([26] 29-36 [38] x [20] 22-26 [28] $\mu \mathrm{m}$ ).

Three Puccinia species have been reported on species of Tabernaemontana: $P$. engleriana, $P$. tabernaemontana and $P$. morobensis (Farr \& Rossman, 2010). Puccinia engleriana differs from the South
Florida and Cuban specimens of $U$. manilensis by its larger teliospores ([32] 35-41 [45] x [21] 22-24 um). Puccinia tabernaemontana has larger urediniospores (34-41[45] x 26-32 [34] $\mu \mathrm{m})$ and yellow-brown, poorly echinulated to almost smooth teliospores. Meanwhile, teliospores (24-29 x $33-45 \mu \mathrm{m})$ and urediniospores $(23-28 \times 29-35 \mu \mathrm{m})$ of $P$. morobensis are larger and the pedicels are very short and fragile (Perez et al., 2008). This is the first report of $U$. manilensis in Cuba and the second report in the Western Hemisphere after the report in South Florida (Perez et al., 2008). Also, this is the second time a telial stage (provisionally P. manilensis) has been recognised for this fungus.

\section{Acknowledgements}

We sincerely thank J. M. Perez, Brooks Tropical, for his helpful advice.

\section{References}

Farr DF, Rossman AY, 2010. Fungal Databases, Systematic Mycology and Microbiology Laboratory, ARS, USDA. Retrieved November 21, 2010 from http://nt.ars-grin.gov/fungaldatabases/.

Perez JM, Palmateer AJ, Ploetz RC, Cating RA, Lynn JM, 2008. First Report of Uredo manilensis in the Western Hemisphere. Plant Disease 92 , 1711. [doi:10.1094/PDIS-92-12-1711B]

Sydow H, Sydow P, 1910. Fungi novi Phillippinenses. Annals of Mycology 8, 36-41.

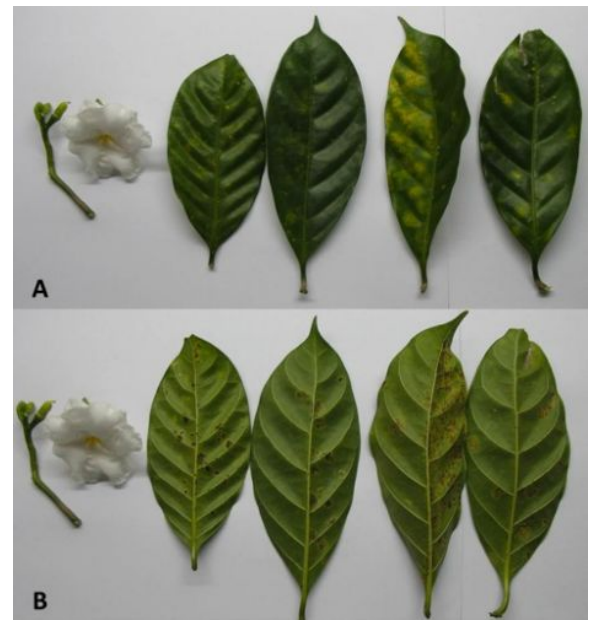

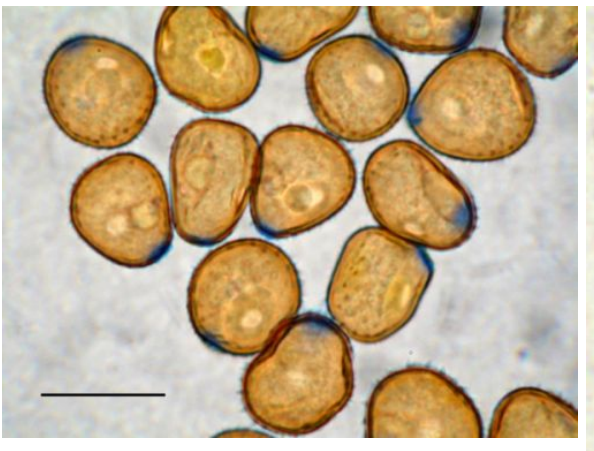

Figure 2

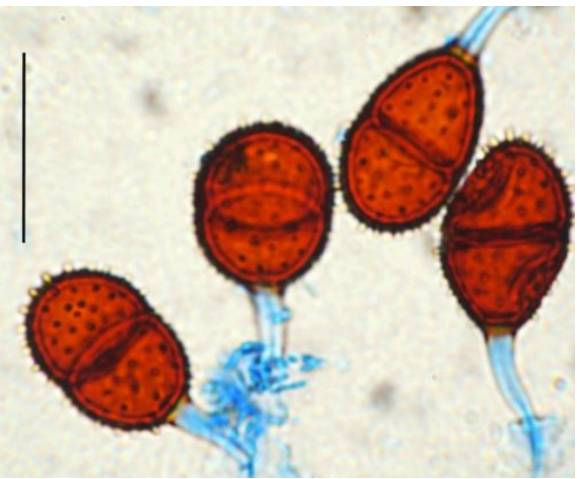

Figure 3

Figure 1

To cite this report: Martínez-de la Parte E, Cantillo-Pérez T, García D, Guerrero-Barriel D, 2011. Crepe jasmine rust caused by Uredo manilensis newly reported in Cuba. New Disease Reports 23, 32. [doi:10.5197/j.2044-0588.2011.023.032] 